\title{
Kinetics and mechanism of electron transfer processes in a hydrogen peroxide-trispicolinatoruthenate(II) system
}

\author{
Olga Impert • Anna Katafias • Joanna Fenska • \\ Przemysław Kita
}

Received: 19 September 2011/ Accepted: 7 October 2011/Published online: 26 October 2011

(C) The Author(s) 2011. This article is published with open access at Springerlink.com

\begin{abstract}
Oxidation of trispicolinatoruthenate(II) complex by hydrogen peroxide leads to the formation of mertrispicolinatoruthenium(III) in acidic or neutral solutions. Kinetics of the reaction were studied under a large excess of $\mathrm{H}_{2} \mathrm{O}_{2}$ at constant $\mathrm{pH}$. The initial rate method gives a rate expression of the form: $-\mathrm{d}[\mathrm{Ru}(\mathrm{II})] / \mathrm{d} t=k^{I I}\left[\mathrm{H}_{2} \mathrm{O}_{2}\right][\mathrm{Ru}(\mathrm{II})]$ but the overall process examined till completion is far more complex. The rate of the reaction decreases with increasing $\mathrm{pH}$ to be practically completely retarded in alkaline media. The key step in the proposed reaction mechanism is the picolinato chelate ring opening followed by the substitution of the coordinated water by $\mathrm{H}_{2} \mathrm{O}_{2}$ and two-electron intramolecular ruthenium(II) oxidation. Formation of the final ruthenium(III) complex is assigned rather to the ruthenium(IV) reduction by $\mathrm{H}_{2} \mathrm{O}_{2}$ than ruthenium(II)-ruthenium(IV) comproportionation. The obtained results show the much slower rate of the trispicolinatoruthenate(II) oxidation by hydrogen peroxide or dioxygen than the mertrispicolinatoruthenium(III) reduction by such bioreductants as cytochrome cII or some cobalt(II) reductants.
\end{abstract}

\section{Introduction}

Hydrogen peroxide, one of the reactive oxygen species (ROS), is a common by-product of aerobic life and physiological energy metabolism. It can be generated within mitochondria in oxidative phosphorylation during which dioxygen is reduced to water in a four electron redox process. Up to $5 \%$ of $\mathrm{O}_{2}$ consumed by mitochondria is

O. Impert $(\bowtie) \cdot$ A. Katafias $\cdot$ J. Fenska $\cdot$ P. Kita

Faculty of Chemistry, N. Copernicus University, 87-100 Torun, Poland

e-mail: oimpert@umk.pl converted to superoxide, hydrogen peroxide, and other reactive oxygen species under normal physiologic conditions [1]. The superoxide radical is transformed by superoxide dismutase into hydrogen peroxide, which is then converted by glutathione peroxidase and catalase into $\mathrm{H}_{2} \mathrm{O}$. The mentioned reactive oxygen species play a much more complex role in living cells than just participation in the electron transport chain. They are beneficial, as they are used by the immune system to kill pathogens. However, ROS induced oxidative damage of DNA, proteins, lipids, and other cellular components causes over 150 diseases [2]. Moreover, it was shown that besides DNA damage, hydrogen peroxide induces cell proliferation, invasion, metastasis, and angiogenesis as well as apoptosis resistance, thus probably plays a key role in carcinogenesis [3]. On the other hand, there is evidence that tumor cells are more susceptible to $\mathrm{H}_{2} \mathrm{O}_{2}$-induced apoptosis than normal ones. Therefore, hydrogen peroxide may be useful in cancer therapy [3].

The toxicity of $\mathrm{H}_{2} \mathrm{O}_{2}$, one of the most stable ROS, results from its interactions with transition metal complexes. Previously, it was commonly assumed that low-valent transition metal ions are responsible for the reduction of hydrogen peroxide to the extremely reactive and biologically destructive hydroxyl radicals [3]. The most recent kinetic and mechanistic studies give evidence that the above interactions usually do not lead to $\mathrm{OH}$ generation but to the strongly oxidizing high-valent metal oxocomplexes [4]. Some possible pathways of the latter species formation and their decay are presented in Scheme 1.

The proposed transition metal transformations were established on the basis of the kinetic data obtained mainly for iron(II)/(III) and manganese(II)/(III) complexes [5, 6]. Much less information is available for ruthenium(II)/(III) ions in spite of their potential anticancer properties. It 
Scheme 1 Some possible ways of formation of high-valent metal oxocomplexes

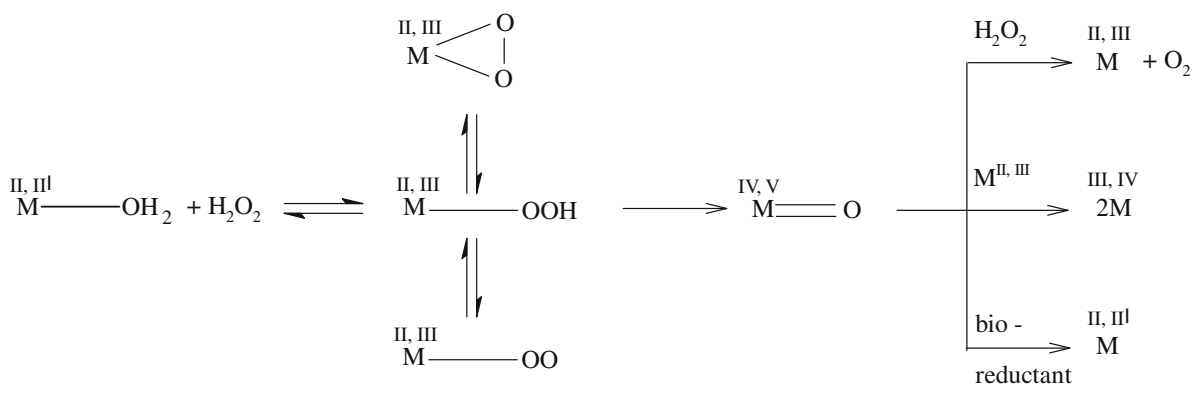

seems that some ruthenium complexes may be a promising alternative to platinum anticancer drugs $[7,8]$ due to (1) their lower toxicity attributed to their higher specificity for their targets, (2) the marked efficacy against metastases, and (3) a selective activation by reduction in cytotoxic species within the tumor. Growing interest in ruthenium compounds requires an elucidation of their redox transformations caused by biological redox agents. Under physiological conditions, ruthenium exists at $+3,+2$, and for a short time also at +4 oxidation states. In the presence of bioreductants, ruthenium species are transformed into ruthenium(II), whereas oxidants shift redox equilibria mainly to ruthenium(IV). Ruthenium(II) and ruthenium(IV) can be formed also via disproportionation of ruthenium(III). It has been found that cyclometalated ruthenium(II) complexes are efficient redox mediators in peroxidase catalysis [9]. The ruthenium drugs which have recently completed or entered phase I clinical trials include either ruthenium(III), like NAMI-A (trans-[ $\mathrm{RuCl}_{4}$ $(\mathrm{dmso})(\mathrm{Im})]$ where $\mathrm{dmso}=$ dimethyl sulphoxide, $\mathrm{Im}=$ imidazole) and $\mathrm{KP} 1019$ (trans- $\left[\mathrm{RuCl}_{4}(\mathrm{Ind})_{2}\right]$ where Ind = $1 \mathrm{H}$-indazole) or several ruthenium(II) coordination compounds, e.g., [10]. It has been suggested that reduction of $\mathrm{Ru}(\mathrm{III})$ pro-drugs forms biologically more active $\mathrm{Ru}(\mathrm{II})$ species. It has been well documented that ruthenium(II) compounds inhibit the tumor growth at submicromolar concentration. Kinetics and mechanism of NAMI-A reduction to its ruthenium(II) analog have been studied recently by Brindell et al. [11, 12].

One of the criteria for selecting ligands to design a metal complex as a drug candidate is their ability to promote the absorption of metals into the body. In this study, we have chosen picolinate (pic, 2-pyridinecarboxylate) as a ligand, since it is successfully applied as a metal transporter into living organisms.

Mer-Cr(pic $)_{3}$ is the most common commercial source of synthetic biochromium [13]; $\mathrm{Zn}$ (pic) ${ }_{2}$ candidates for insulin-mimetic drug and serves as dietary supplement supporting the immune system, providing antioxidant protection [14], and vanadium(IV)/(V) picolinato complexes are promising for enhanced insulin activity [15]. $M e r-\mathrm{Ru}(\mathrm{pic})_{3}$ has been synthesized and characterized in the 90's [16, 17] but to date has not been tested as a cancer drug candidate; moreover, its fundamental reactions of ligand substitution and redox transformations in vitro are unknown. The aim of this work is an elucidation of the role played by hydrogen peroxide in oxidation of trispicolinatoruthenate(II) anion. To the best of our knowledge, kinetics and mechanism of this process have not been examined yet. The obtained kinetic data should facilitate an evaluation of the importance of the ruthenium(II) deactivation processes by reactive oxygen species inhibiting the ruthenium interactions with nucleic acids.

\section{Materials and methods}

Materials and solution preparation

All chemicals were obtained from POCh (Poland), SigmaAldrich or Merck as pro analysis grade and used without further purification. Solutions were prepared with water deionized and redistilled from alkaline permanganate.

Mer- $\left[\mathrm{Ru}(\mathrm{pic})_{3}\right] \cdot \mathrm{H}_{2} \mathrm{O}$ was synthesized following the procedure published before [18]. $\left[\mathrm{Ru}(\mathrm{pic})_{3}\right]^{-}$was obtained by the reduction of its ruthenium(III) analog in aqueous solution by europium(II) under argon and stored under anaerobic conditions to prevent its autoxidation. The $\mathrm{Ru}(\mathrm{II})$ concentration was determined spectrophotometrically, using the molar absorption coefficient given in the literature [19], i.e., $\varepsilon_{466}=1.2 \times 10^{4} \mathrm{M}^{-1} \mathrm{~cm}^{-1}$.

Britton-Robinson buffer solutions used to control pH were prepared applying $0.04 \mathrm{M} \mathrm{H}_{3} \mathrm{PO}_{4}, 0.04 \mathrm{M} \mathrm{H}_{3} \mathrm{BO}_{3}$, $0.04 \mathrm{M} \mathrm{CH}_{3} \mathrm{COOH}$, and $0.2 \mathrm{M} \mathrm{NaOH}$.

\section{Measurements}

$\mathrm{pH}$ measurements of buffered solutions were performed with a multifunction computer ELMETRON CX-731 meter.

Electro-spray ionization mass spectrometric measurements were conducted for the substrate aqueous solutions of $\mathrm{pH} 3$ using a Micromass Q-TOF instrument. The spectrum seen in Fig. 1 exhibits eight line patterns due to the 


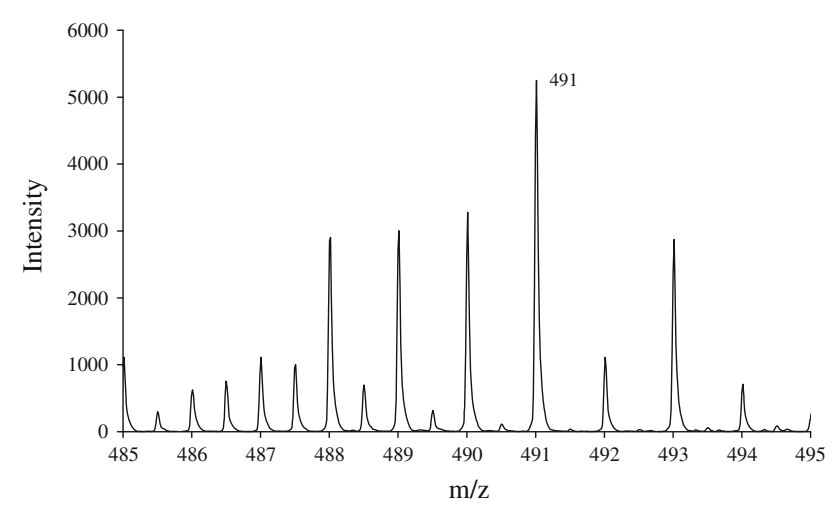

Fig. 1 Electro-spray ionization mass spectrum of $\left[\mathrm{Ru}(\mathrm{pic})_{3}\right]$ at $\mathrm{pH}=3 ;\left[\mathrm{Ru}^{\mathrm{III}}\right]=5 \times 10^{-5} \mathrm{M}$

various isotopes, centered around ${ }^{101} \mathrm{Ru}$. The main peak at $\mathrm{m} / \mathrm{z}=491$ is attributed to the trispicolinatoruthenium(III) complex.

Autoxidation and oxidation of $m e r-\left[\mathrm{Ru}(\mathrm{pic})_{3}\right]^{-}$by hydrogen peroxide were followed spectrophotometrically with a HP 8453 diode-array spectrophotometer equipped with HP 89090 Peltier Temperature Controller. They were monitored as an absorbance decrease at $472 \mathrm{~nm}$, within the MLCT transition band characteristic for ruthenium(II) complex. Additional measurements were performed with a Shimadzu UV-1601 PC spectrophotometer to evaluate photochemical processes induced by the diode-array instrument.

Kinetic experiments were carried out under pseudo-first order limiting conditions: $[\mathrm{Ru}(\mathrm{II})]=(6.4-9.6) \times 10^{-5} \mathrm{M}$, $\left[\mathrm{H}_{2} \mathrm{O}_{2}\right]=0.01-0.2 \mathrm{M},\left[\mathrm{H}_{\mathrm{aq}}^{+}\right]=0.01-1.0 \mathrm{M}$ at $T=298 \mathrm{~K}$ and additionally at $\mathrm{pH} 7.4$ at $T=298$ and $310 \mathrm{~K}$. The rate of the autoxidation process was measured at $\mathrm{pH} 1$ and 7.4 at $T=298$ and $310 \mathrm{~K}$. The reactions were started by an injection of $0.1 \mathrm{~mL}$ of the hydrogen peroxide stock solution or the ruthenium(II) stock solution (autoxidation process) into a thermostated reaction mixture $(1.9 \mathrm{~mL})$ of the final ionic strength kept constant with $\mathrm{NaClO}_{4}$ (in some experiments also with $\mathrm{NaCl}$ ). The reported rate constants are mean values from at last three kinetic runs.

Cyclic voltammetry measurements were obtained in an aqueous solution with $0.1 \mathrm{M} \mathrm{NaClO}_{4}$ as the supporting electrolyte and $1 \times 10^{-4} \mathrm{M}$ ruthenium(III) complex using glassy carbon as working, $\mathrm{Pt}$ as counter, and $\mathrm{Ag} / \mathrm{AgCl}$ as reference electrodes on an AUTOLAB/PGSTAT $128 \mathrm{~N}$ Potentiostat/Galvanostat. Cyclic voltammograms were obtained under argon at ambient temperature. The results are presented in Fig. 2. $E_{1 / 2}$ values were calculated from the average anodic and cathodic peak potentials, $E_{1 / 2}=0.5\left(E_{\mathrm{a}}+E_{\mathrm{c}}\right)$. The final values are reported versus standard hydrogen electrode.

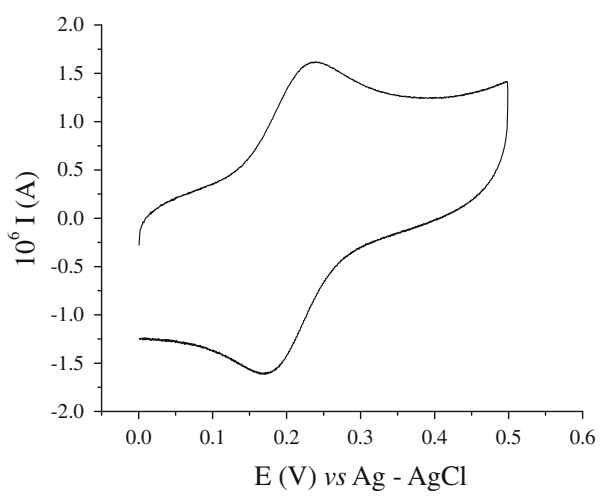

Fig. 2 Cyclic voltammogram of $1 \times 10^{-4} \mathrm{M}$ mer- $\left[\mathrm{Ru}^{\mathrm{III}}(\text { pic })_{3}\right]$ in $0.1 \mathrm{M} \mathrm{NaClO}_{4}$ solution at scan rate $100 \mathrm{mV} / \mathrm{s}$

\section{Results and discussion}

Picolinic acid, shown in Scheme 2, effectively coordinates ruthenium(III) through the pyridine nitrogen and carboxylato group oxygen atoms forming well-characterized mertrispicolinatoruthenium(III) [17].

The intense red-colored solution of trispicolinatoruthenate(II) anion has been obtained by reduction of the pale yellow solution of $m e r-\left[\mathrm{Ru}(\mathrm{pic})_{3}\right]$ using europium(II) under argon atmosphere. Spectral differences between the mentioned complexes are presented in Fig. 3.

The most characteristic for the $\left[\mathrm{Ru}(\mathrm{pic})_{3}\right]^{-}$is an intense band in the visible region assigned to the MLCT transition $[20,21]$. The intraligand $\pi-\pi^{*}$ transition band at $257 \mathrm{~nm}$ is also remarkably more intense for the ruthenium(II) than for its ruthenium(III) analog. The redox potential of a $\mathrm{Ru}(\mathrm{III}) /$ $\mathrm{Ru}(\mathrm{II})$ couple strongly depends on the coordination sphere composition; standard potentials ranging from 0 to $1.5 \mathrm{~V}$ are known [22]. The electrochemical reversible $\left[\mathrm{Ru}(\mathrm{pic})_{3}\right]^{-}$ to $\left[\mathrm{Ru}(\mathrm{pic})_{3}\right]^{0}$ oxidation in an aqueous solution $(0.1 \mathrm{M}$ $\mathrm{NaClO}_{4}$ ) was observed by us at $0.330 \mathrm{~V}$ versus NHE, Fig. 2 . The low value of $E_{\mathrm{Ru}(\mathrm{III}) / \mathrm{Ru}(\mathrm{II})}$ for the couple under consideration makes the ruthenium(II) oxidation a thermodynamically favorable process even by mild oxidants. The complex examined in this work contains no water molecules in the inner coordination sphere which makes it a significantly different reactant than those ruthenium(II) species oxidized by hydrogen peroxide in other laboratories [21, 23, 24]. Our preliminary experiments have demonstrated an exceptional

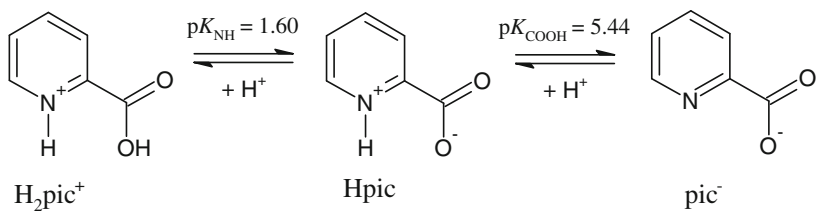

Scheme 2 Protolytic equilibria of picolinic acid 


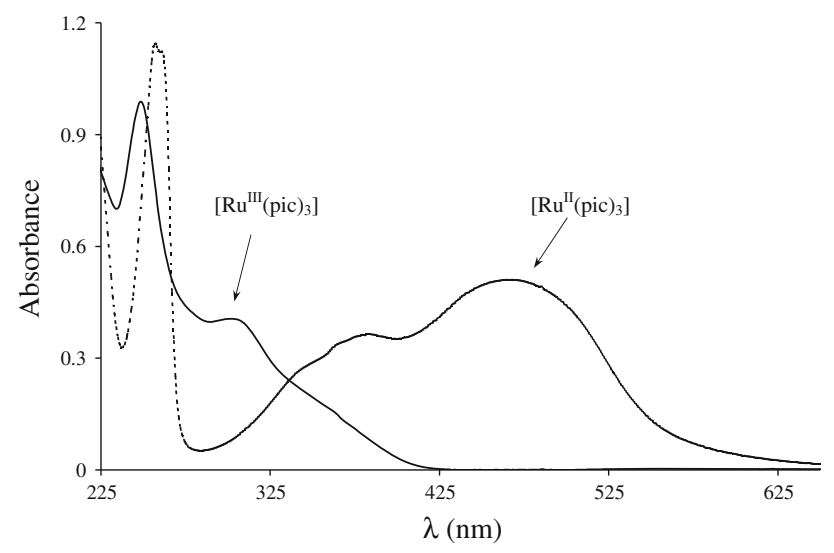

Fig. 3 Electronic spectra of trispicolinate complexes of ruthenium; $[\mathrm{Ru}(\mathrm{III})]=[\mathrm{Ru}(\mathrm{II})]=4.3 \times 10^{-5} \mathrm{M},\left[\mathrm{H}_{3} \mathrm{O}^{+}\right]=0.1 \mathrm{M}, l=1 \mathrm{~cm}$

inertness of both $\left[\mathrm{Ru}(\mathrm{pic})_{3}\right]^{0 /-}$ complexes in acidic and neutral solutions, retarding the formation of their aqua derivatives in spectroscopically observed amounts.

The $\left[\mathrm{Ru}(\mathrm{pic})_{3}\right]^{-}$anion is slowly reoxidized by hydrogen peroxide to its parent complex, mer- $\left[\mathrm{Ru}^{\mathrm{III}}(\mathrm{pic})_{3}\right]$ isomer, without any changes within the inner coordination sphere. This is deduced from the practically identical spectra of the starting $\mathrm{Ru}(\mathrm{III})$ and the oxidation product of $\mathrm{Ru}(\mathrm{II})$, Fig. 3 and the mass spectrum, Fig. 1, showing the dominant peak at $m / z=491$, which corresponds to the theoretical compositions of $m e r-\left[\mathrm{Ru}^{\mathrm{III}}(\mathrm{pic})_{3}\right]$ - the predominant reaction product. The overall redox process is described by Eq. 1:

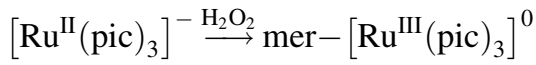

The presence of only two absorbing species in the reaction mixture during the reaction course is confirmed by sharp isosbestic points at 256, 267, and $340 \mathrm{~nm}$, Fig. 4. In alkaline solutions, neither trispicolinatoruthenate(II) oxidation nor ruthenium catalyzed hydrogen peroxide decomposition are observed. Additional tests proved no reaction between the mer- $\left[\mathrm{Ru}^{\mathrm{III}}(\mathrm{pic})_{3}\right]$ and $\mathrm{H}_{2} \mathrm{O}_{2}$ within a wide $\mathrm{pH}$ range. Kinetic measurements of the oxidation of the $\left[\mathrm{Ru}^{\mathrm{II}}(\mathrm{pic})_{3}\right]^{-}$anion by hydrogen peroxide were preceded by an evaluation of the autoxidation rate in dioxygen-saturated solutions, Fig. 5. The registered spectral changes are similar to those for the reaction (1) but the rate of the autoxidation process is faster than the rate of the oxidation by hydrogen peroxide. The autoxidation of the $\left[\mathrm{Ru}^{\mathrm{II}}(\mathrm{pic})_{3}\right]^{-}$ion upon a long time exposure to air observed by Bhattacharya et al. [17] results in ca. $60 \%$ regeneration of the $m e r-\left[\mathrm{Ru}^{\mathrm{III}}(\mathrm{pic})_{3}\right]$, evaluated by intensity measurements of the spectral bands. In contrast, much shorter time of the oxidation with hydrogen peroxide results in the virtually complete conversion of the $\left[\mathrm{Ru}^{\mathrm{II}}(\mathrm{pic})_{3}\right]^{-}$anion into the $m e r-\left[\mathrm{Ru}^{\mathrm{III}}(\mathrm{pic})_{3}\right]$ species.

The kinetics of the reaction (1) have been studied under a large excess of the oxidant and at constant $\mathrm{pH}$. In spite of

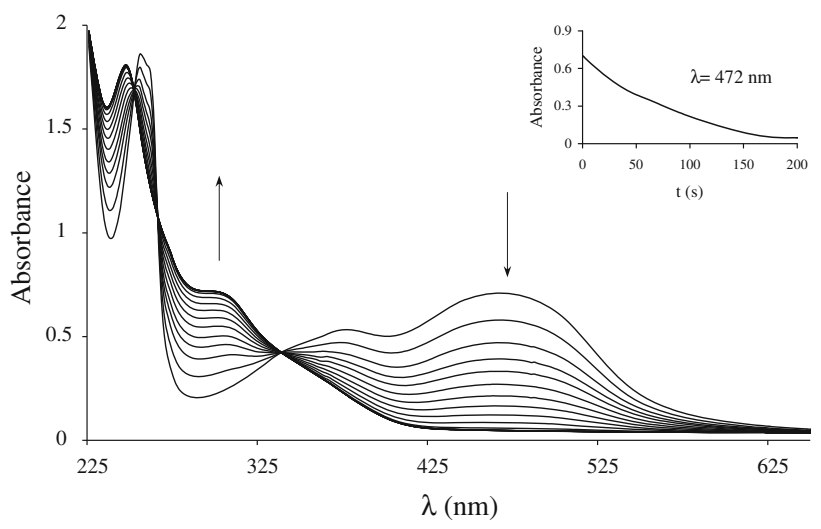

Fig. 4 UV-Vis spectral changes observed during the oxidation of the $\left[\mathrm{Ru}^{\mathrm{II}}(\mathrm{pic})_{3}\right]^{-}$complex by hydrogen peroxide; $[\mathrm{Ru}(\mathrm{II})]=8 \times$ $10^{-5} \mathrm{M},\left[\mathrm{H}_{2} \mathrm{O}_{2}\right]=0.01 \mathrm{M},\left[\mathrm{H}_{3} \mathrm{O}^{+}\right]=0.1 \mathrm{M}, T=298 \mathrm{~K}, l=1 \mathrm{~cm}$, scans taken every $15 \mathrm{~s}$

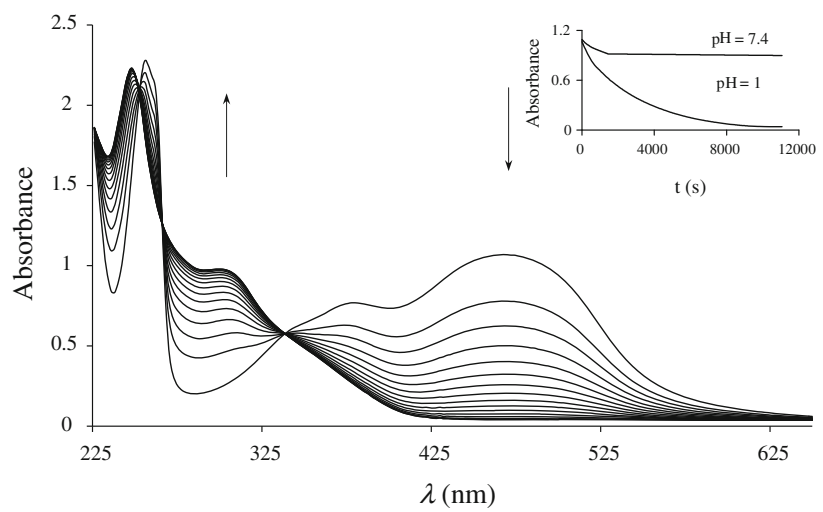

Fig. 5 UV-Vis spectral changes observed during the autoxidation of the $\left[\mathrm{Ru}^{\mathrm{II}}(\mathrm{pic})_{3}\right]^{-}$complex under $\mathrm{O}_{2}$ atmosphere; $[\mathrm{Ru}(\mathrm{II})]=8 \times$ $10^{-5} \mathrm{M},\left[\mathrm{H}_{3} \mathrm{O}^{+}\right]=0.1 \mathrm{M}, T=298 \mathrm{~K}, l=1 \mathrm{~cm}$, scans taken every $12 \mathrm{~min}$; inset: kinetic traces at $\lambda=472 \mathrm{~nm}$

the apparent simplicity of the overall spectra, Fig. 4, the kinetic traces recorded within varying spectral ranges are far more complex than those expected for the simple firstorder or consecutive first-order reactions. Kinetic data found by others for a few ruthenium complexes containing at least one water (in the form of aqua, hydroxo, or oxo ligands) in the inner coordination sphere also proved very complex, multistep mechanisms of reactions in ruthenium complexes hydrogen peroxide systems. Meyer et al. [23] have documented the reduction of $\mathrm{Ru}(\mathrm{IV})$ and $\mathrm{Ru}(\mathrm{III})$ by $\mathrm{H}_{2} \mathrm{O}_{2}$ in a wide $\mathrm{pH}$ range, whereas Drago et al. [21] and van Eldik et al. [24] have found oxidation of $\mathrm{Ru}(\mathrm{II})$ and $\mathrm{Ru}(\mathrm{III})$, respectively, by $\mathrm{H}_{2} \mathrm{O}_{2}$ to $\mathrm{Ru}(\mathrm{IV}), \mathrm{Ru}(\mathrm{V})$, and even $\mathrm{Ru}(\mathrm{VI})$. Complicated absorbances versus time changes were analyzed applying different methods: the initial rate method [21], the first-order method for the limited range of conversion degree (up to $2-3 t_{1 / 2}$ ) [23], or a double exponential first-order rate expression [24]. We have decided to 
Table 1 Values of the pseudozeroth-order rate constants for the autoxidation of trispicolinatoruthenate(II); $[\mathrm{Ru}(\mathrm{II})]=8.0 \times 10^{-5} \mathrm{M}$, $I=1.0 \mathrm{M}$

a Britton-Robinson buffer

\begin{tabular}{|c|c|c|c|c|}
\hline \multirow[t]{3}{*}[\mathrm{H}_{\mathrm{aq}}^{+}]{$(\mathrm{M})$} & \multicolumn{4}{|l|}{$10^{9} k_{\mathrm{obs}}^{0}\left(\mathrm{Ms}^{-1}\right)$} \\
\hline & \multicolumn{2}{|l|}{ Air atmosphere } & \multicolumn{2}{|c|}{$\mathrm{O}_{2}$ atmosphere } \\
\hline & $298 \mathrm{~K}$ & $310 \mathrm{~K}$ & $298 \mathrm{~K}$ & $310 \mathrm{~K}$ \\
\hline 1.0 & $8 \pm \ll 1$ & & $39 \pm 1$ & \\
\hline 0.40 & $8 \pm \ll 1$ & & $37 \pm 1$ & \\
\hline 0.10 & $7 \pm \ll 1$ & $17 \pm \ll 1$ & $36 \pm 1$ & $81 \pm 1$ \\
\hline 0.05 & $7 \pm \ll 1$ & & $35 \pm 1$ & \\
\hline $4 \times 10^{-8 a}$ & $0.06 \pm \ll 0.01$ & $0.2 \pm \ll 0.1$ & $0.3 \pm \ll 0.1$ & $0.9 \pm \ll 0.1$ \\
\hline
\end{tabular}

Table 2 Values of the pseudozeroth-order rate constants for the oxidation of trispicolinatoruthenate(II) by hydrogen peroxide; $I=1.0 \mathrm{M}$ $\left(\mathrm{Na}^{+}, \mathrm{H}^{+}, \mathrm{ClO}_{4}^{-}\right), T=298 \mathrm{~K}$ (unless otherwise stated)
${ }^{\mathrm{a}} T=283 \mathrm{~K},{ }^{\mathrm{b}} T=288 \mathrm{~K}$,

${ }^{\mathrm{c}} T=293 \mathrm{~K},{ }^{\mathrm{d}} T=303 \mathrm{~K}$,

${ }^{\mathrm{e}} T=313 \mathrm{~K},{ }^{\mathrm{f}} I=0.1 \mathrm{M}$,

${ }^{\mathrm{g}} I=0.2 \mathrm{M},{ }^{\mathrm{h}} I=0.5 \mathrm{M}$,

${ }^{\mathrm{i}} I=1.5 \mathrm{M},{ }^{\mathrm{j}} I=2.0 \mathrm{M}$,

${ }^{\mathrm{k}}$ Britton-Robinson buffer,

${ }^{1} I=0.1 \mathrm{M}\left(\mathrm{Na}^{+}, \mathrm{H}^{+}, \mathrm{Cl}^{-}\right)$,

${ }^{\mathrm{m}} T=310 \mathrm{~K}$

\begin{tabular}{llll}
\hline $10^{5}[\mathrm{Ru}(\mathrm{II})](\mathrm{M})$ & {$\left[\mathrm{H}_{2} \mathrm{O}_{2}\right](\mathrm{M})$} & {$\left[\mathrm{H}_{3} \mathrm{O}^{+}\right](\mathrm{M})$} & $10^{7} k_{\text {obs }}^{0}\left(\mathrm{Ms}^{-1}\right)$ \\
\hline 8.0 & 0.01 & 1.0 & $25.5 \pm 0.5$ \\
& 0.80 & $21.2 \pm 0.6$ \\
& 0.60 & $16.8 \pm<0.1$ \\
& 0.40 & $12.7 \pm 0.1$ \\
& 0.20 & $7.79 \pm 0.02$ \\
& 0.10 & $6.38 \pm 0.09,2.02 \pm 0.03^{\mathrm{a}}, 2.48 \pm 0.03^{\mathrm{b}}$, \\
& & $4.23 \pm 0.05^{\mathrm{c}}, 8.27 \pm 0.09^{\mathrm{d}}, 17.6 \pm 0.2^{\mathrm{e}}$, \\
& & $6.0 \pm 0.3^{\mathrm{f}}, 5.8 \pm 0.1^{\mathrm{g}}, 5.88 \pm 0.08^{\mathrm{h}}$, \\
& & $6.2 \pm 0.2^{\mathrm{i}}, 6.23 \pm 0.06^{\mathrm{j}}, 10.5 \pm 0.1^{1}$, \\
& & $5.08 \pm 0.07$ \\
& & $4.21 \pm 0.05$ \\
& & $0.15 \pm 0.01,0.23 \pm 0.01^{1}, 0.26 \pm 0.01^{\mathrm{m}}$, \\
& & $0.39 \pm 0.01^{1, \mathrm{~m}}$ \\
& & & $7.92 \pm 0.02$ \\
& & & $15.2 \pm 0.4$ \\
& & $26.3 \pm 0.8$ \\
& & & $37.5 \pm 0.7$ \\
6.4 & 0.1 & & $48.0 \pm 0.9$ \\
& 0.05 & & $4.86 \pm 0.06$ \\
& 0.10 & & $6.57 \pm 0.02$ \\
\hline
\end{tabular}

use the zeroth-order rate method analyzing a linear absorbance versus time dependence for $10 \%$ of the total absorbance decrease $(\Delta \mathrm{A}=0.1-0.15)$.

The almost identical results were obtained on either side of the isosbestic point, i.e., at 304 and $472 \mathrm{~nm}$. The kinetic data for the autoxidation and the oxidation by hydrogen peroxide processes are summarized in Tables 1 and 2 . The pseudo-zeroth-order rate constant $k_{\mathrm{obs}}^{0}$ is independent of the ionic strength and is $50 \%$ higher in chloride media. The $k_{\mathrm{obs}}^{0}$ is proportional to the initial ruthenium(II) concentration; therefore, the $k_{\mathrm{obs}}^{0} /[\mathrm{Ru}(\mathrm{II})]_{0}=k^{\mathrm{I}}$, where $k^{\mathrm{I}}$ is the pseudo-first-order rate constant dependent on the applied $\mathrm{H}_{2} \mathrm{O}_{2}$ concentration and $\mathrm{pH}$. The $k^{\mathrm{I}}$ value linearly increases with $\left[\mathrm{H}_{2} \mathrm{O}_{2}\right]$, as seen in Fig. 6, proving a firstorder dependence on the oxidant concentration.
The pseudo-second-order rate constant, $k^{\mathrm{II}}$, determined from the slope is a commonly used measure of the reactivity of ruthenium complexes at constant $\left[\mathrm{H}_{\mathrm{aq}}^{+}\right]$. The rate expression for the low values of the conversion degree is of the form:

$-\frac{\mathrm{d}[\mathrm{Ru}(\mathrm{II})]}{\mathrm{d} t}=k^{\mathrm{II}}\left[\mathrm{H}_{2} \mathrm{O}_{2}\right][\mathrm{Ru}(\mathrm{II})]$

The found value of the $k_{298}^{\mathrm{II}}(\mathrm{pH} 1)$ and the apparent activation parameters calculated from the temperature dependence of the $k^{\mathrm{II}}$ can be compared to a few available literature data for the oxidation of $\mathrm{Ru}(\mathrm{II})$ and $\mathrm{Ru}(\mathrm{III})$ complexes by hydrogen peroxide, collected in Table 3 .

To roughly estimate the temperature dependence of the autoxidation and the oxidation by hydrogen peroxide 


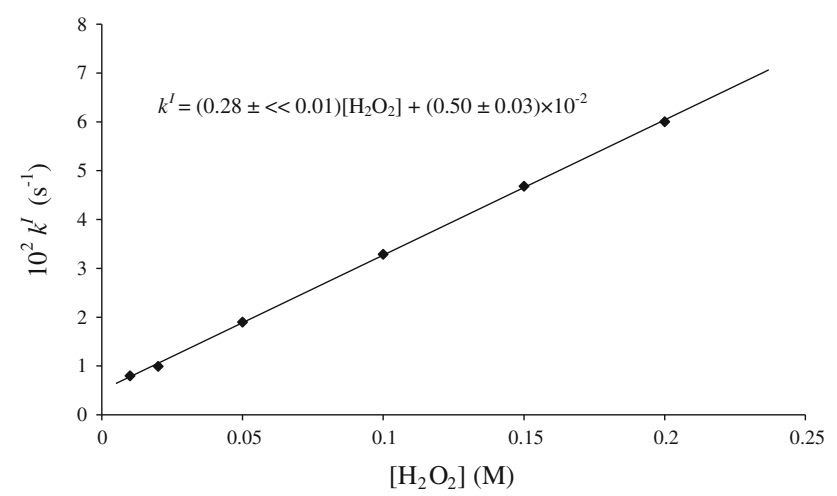

Fig. 6 Hydrogen peroxide concentration dependence of the $k^{\mathrm{I}}$ for the oxidation of the $\left[\mathrm{Ru}(\mathrm{pic})_{3}\right]^{-}$complex by $\mathrm{H}_{2} \mathrm{O}_{2} ;\left[\mathrm{H}_{3} \mathrm{O}^{+}\right]=0.10 \mathrm{M}$, $I=1.0 \mathrm{M}, T=298 \mathrm{~K}$

process at $\mathrm{pH} 7.4$ instead, some measurements were obtained also at $310 \mathrm{~K}$. The temperature coefficient for the former process is ca. 2.5 and for the latter one is ca. 1.5, Tables 1 and 2 .

Kinetic parameters presented in Table 3 demonstrate a similar reactivity of the two ruthenium(II) complexes and the significantly higher reactivity of the ruthenium(III) complex. The astonishingly high reactivity of the ruthenium(III) complex stems from the abnormal lability of the coordinated water in the $\left[\mathrm{Ru}(\mathrm{edta})\left(\mathrm{H}_{2} \mathrm{O}\right)\right]^{-}$complex making the formation of the $[\mathrm{Ru}(\mathrm{edta})(\mathrm{OOH})]^{-}$intermediate a very fast process [24]. Values of the pseudosecond-order rate constant for the oxidation of the trispicolinatoruthenate(II) linearly increase with $\left[\mathrm{H}_{\mathrm{aq}}^{+}\right]$as shown in Fig. 7.

It is very remarkable that the intercept equal to $0.5 \mathrm{M}^{-1} \mathrm{~s}^{-1}$ (Fig. 7) is much larger than the $k^{\mathrm{II}}$ determined directly at $\mathrm{pH} 7.4$ being equal to $0.002 \mathrm{M}^{-1} \mathrm{~s}^{-1}$ (Table 3), suggesting some reversibility of the redox process. A strong dependence of the pseudo-second-order rate constant on $\mathrm{pH}$ found in this work, Fig. 8, makes the comparison of the ruthenium complexes reactivity a difficult problem. The initial rates of the $\left[\mathrm{Ru}(\mathrm{dmphen})_{2}\left(\mathrm{H}_{2} \mathrm{O}\right)_{2}\right]^{2+}$ (dmphen-2,9-dimethyl-1,10-phenantroline) oxidation by $\mathrm{H}_{2} \mathrm{O}_{2}$ are $\mathrm{pH}$ independent (within 3-9 pH range) [21], and the data for the $\left[\mathrm{Ru}(\text { edta })\left(\mathrm{H}_{2} \mathrm{O}\right)\right]^{-}$oxidation are obtained only at pH 5.1 [24]. Therefore, it seems that to compare the reactivity of the mentioned complexes at higher $\mathrm{pH}$ (ca.5),

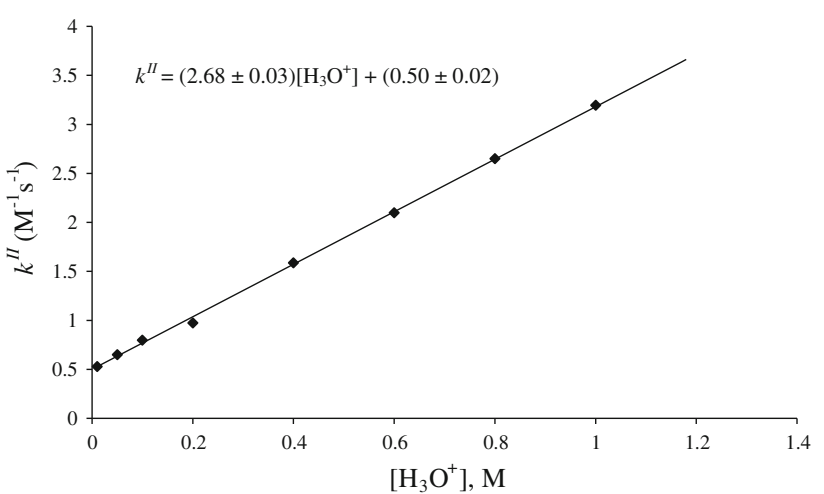

Fig. $7 \mathrm{H}_{3} \mathrm{O}^{+}$concentration dependence of the $k^{\mathrm{II}}$ for the oxidation of the $\left[\mathrm{Ru}(\mathrm{pic})_{3}\right]^{-}$complex by $\mathrm{H}_{2} \mathrm{O}_{2} ; I=1.0 \mathrm{M}, T=298 \mathrm{~K}$

the value of the pseudo-second-order rate constant for the $\left[\mathrm{Ru}^{\mathrm{II}}(\mathrm{pic})_{3}\right]^{-}$ion found at $\mathrm{pH} 7.4\left(k^{\mathrm{II}}=0.002 \mathrm{M}^{-1} \mathrm{~s}^{-1}\right.$, Table 3) might be used because at this $\mathrm{pH}$ value of the $2.68\left[\mathrm{H}_{a q}^{+}\right]$term (Fig. 7) is very small and can be neglected. This would arrange the considered complexes in the following reactivity order: $\left[\mathrm{Ru}(\text { edta })\left(\mathrm{H}_{2} \mathrm{O}\right)\right]^{-}(13,400)>[\mathrm{Ru}$ $\left.(\text { dmphen })_{2}\left(\mathrm{H}_{2} \mathrm{O}\right)_{2}\right]^{2+}(160)>\left[\mathrm{Ru}^{\mathrm{II}}(\text { pic })_{3}\right]^{-}(1)$, where the values in parenthesis are the pseudo-second-order rate constant ratios. It is worth noting that the reactivity of the trispicolinatoruthenate(II) increases almost 1,600 times at $\mathrm{pH} 0$ because at this $\mathrm{pH}$, the value of the $k^{\mathrm{II}}$ is $3.18 \mathrm{M}^{-1} \mathrm{~s}^{-1}$ (Fig. 7) which changes the $\left[\mathrm{Ru}^{\mathrm{II}}(\text { pic })_{3}\right]^{-}$position in the above reactivity order.

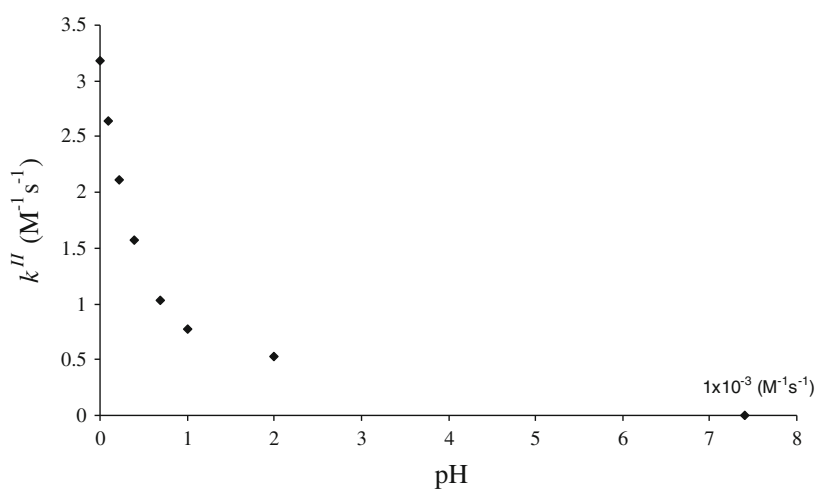

Fig. $8 \mathrm{pH}$ dependence of $k^{\mathrm{II}}$ for the oxidation of the $\left[\mathrm{Ru}(\mathrm{pic})_{3}\right]^{-}$ complex by $\mathrm{H}_{2} \mathrm{O}_{2} ; I=1.0 \mathrm{M}, T=298 \mathrm{~K}$
Table 3 Values of the apparent activation parameters for the oxidation of some ruthenium complexes by hydrogen peroxide

\begin{tabular}{lllllll}
\hline Reductant & Product & $\mathrm{pH}$ & $\begin{array}{l}k_{298}^{I I} \\
\left(\mathrm{M}^{-1} \mathrm{~s}^{-1}\right)\end{array}$ & $\begin{array}{l}\Delta H^{f} \\
\left(\mathrm{~kJ} \mathrm{~mol}^{-1}\right)\end{array}$ & $\begin{array}{l}\Delta S^{f} \\
\left(\mathrm{~J} \mathrm{~K}^{-1} \mathrm{~mol}^{-1}\right)\end{array}$ & Ref. \\
\hline $\begin{array}{c}{\left[\mathrm{Ru}^{\mathrm{II}}(\mathrm{dmphen})_{2}\right.} \\
\left.\left(\mathrm{H}_{2} \mathrm{O}\right)_{2}\right]^{2+}\end{array}$ & $\mathrm{Ru}(\mathrm{IV}) / \mathrm{Ru}(\mathrm{VI})$ & $3.3-9$ & 0.32 & - & - & {$[25]$} \\
{$\left[\mathrm{Ru}^{\mathrm{III}}(\mathrm{edta}) \mathrm{H}_{2} \mathrm{O}\right]^{-}$} & $\mathrm{Ru}(\mathrm{IV}) / \mathrm{Ru}(\mathrm{V})$ & 5.1 & 26.8 & 43 & -72 & {$[26]$} \\
{$\left[\mathrm{Ru}^{\mathrm{II}}(\mathrm{pic})_{3}\right]^{-}$} & $\mathrm{Ru}(\mathrm{III})$ & 1 & 0.75 & $52 \pm 2$ & $-70 \pm 6$ & $\begin{array}{l}\text { This work } \\
{\left[\mathrm{Ru}^{\mathrm{II}}(\mathrm{pic})_{3}\right]^{-}}\end{array}$ \\
\hline
\end{tabular}


Discussion of the reactions in ruthenium complexeshydrogen peroxide systems is based on the Pourbaix diagram for $\mathrm{H}_{2} \mathrm{O}_{2}$ [21]. Three types of processes are observed

$$
\begin{gathered}
\mathrm{Ru}^{\mathrm{II}}-\mathrm{O}-\mathrm{OH} \frac{\text { heterolytic } 2 \mathrm{e}}{\text { bond breaking }} \rightarrow \mathrm{Ru}^{\mathrm{IV}}+\mathrm{H}_{2} \mathrm{O} \\
\mathrm{Ru}-\mathrm{O}-\mathrm{OH} \frac{\text { homolytic } 1 \mathrm{e}}{\text { bond breaking }} \mathrm{Ru}^{\mathrm{III}}+\mathrm{OH}^{*} \\
\mathrm{Ru}^{\mathrm{IV}}-\mathrm{O} \cdots \cdot \mathrm{H}-\mathrm{OOH} \frac{\text { heterolytic }+\mathrm{H}^{+}}{\text {bond breaking }} \mathrm{Ru}^{\mathrm{II}}-\mathrm{OH}_{2}+\mathrm{O}_{2} \\
\mathrm{Ru}^{\mathrm{IV}}-\mathrm{O} \cdots \cdot \mathrm{H}-\mathrm{OOH} \frac{\mathrm{Ru}^{\mathrm{III}}-\mathrm{OH}+\mathrm{HO}_{2}^{\cdot}}{\text { homolytic }}
\end{gathered}
$$

Scheme 3 Some details of some elementary steps of ruthenium redox transformations depending on the composition of the ruthenium coordination sphere, $\mathrm{pH}$ range, and oxidation state of the central ion: (1) oxidation of the ruthenium center up to +6 oxidation state, (2) reduction of the ruthenium ion down to +2 oxidation state, and (3) catalytic decomposition of hydrogen peroxide resulting from cyclic reduction of the ruthenium center at higher oxidation states followed by their reoxidation. Some details of the elementary steps leading to changes in the ruthenium oxidation states are shown in Scheme 3. The overall reaction pattern for the oxidation of the $\left[\mathrm{Ru}^{\mathrm{II}}(\mathrm{pic})_{3}\right]^{-}$complex by hydrogen peroxide proposed based on the current state of our knowledge of redox transformations in transition metals-hydrogen peroxide systems [23-30] is presented in Scheme 4.

Despite the evident limitations of the initial rate method, the two observed kinetic relationships, i.e., the strong rate enhancement with the increasing acidity and hydrogen peroxide concentration, give some insight into the reaction mechanism. These findings prove a large impact of the $\mathrm{H}_{\mathrm{aq}}^{+}$ catalyzed chelate ring opening stage and displacement of the coordinated $\mathrm{H}_{2} \mathrm{O}$ molecule by $\mathrm{H}_{2} \mathrm{O}_{2}$ before the electron
Scheme 4 The overall reaction pattern proposed for the oxidation of the $\left[\mathrm{Ru}^{\mathrm{II}}(\mathrm{pic})_{3}\right]^{-}$ complex by hydrogen peroxide

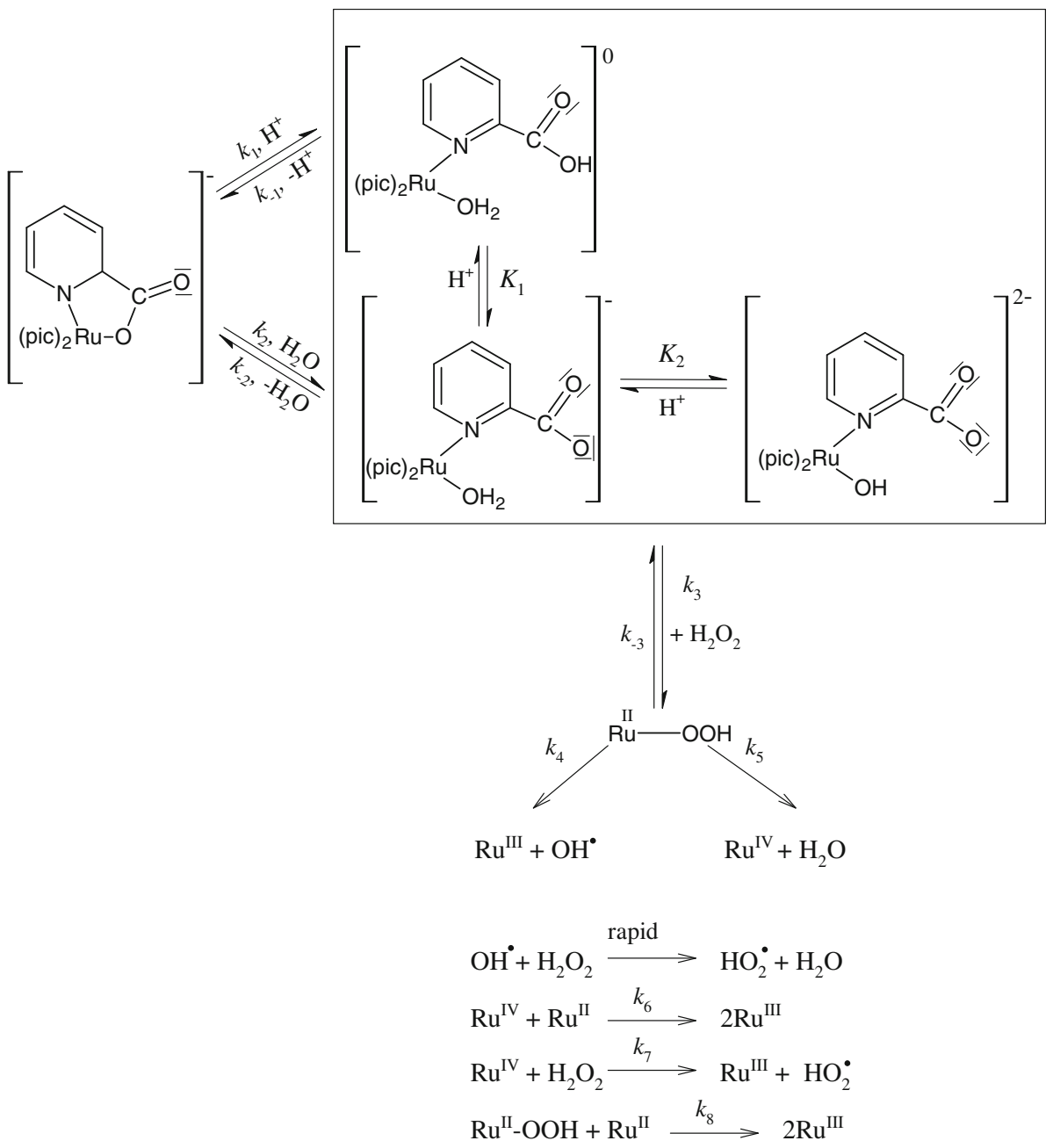



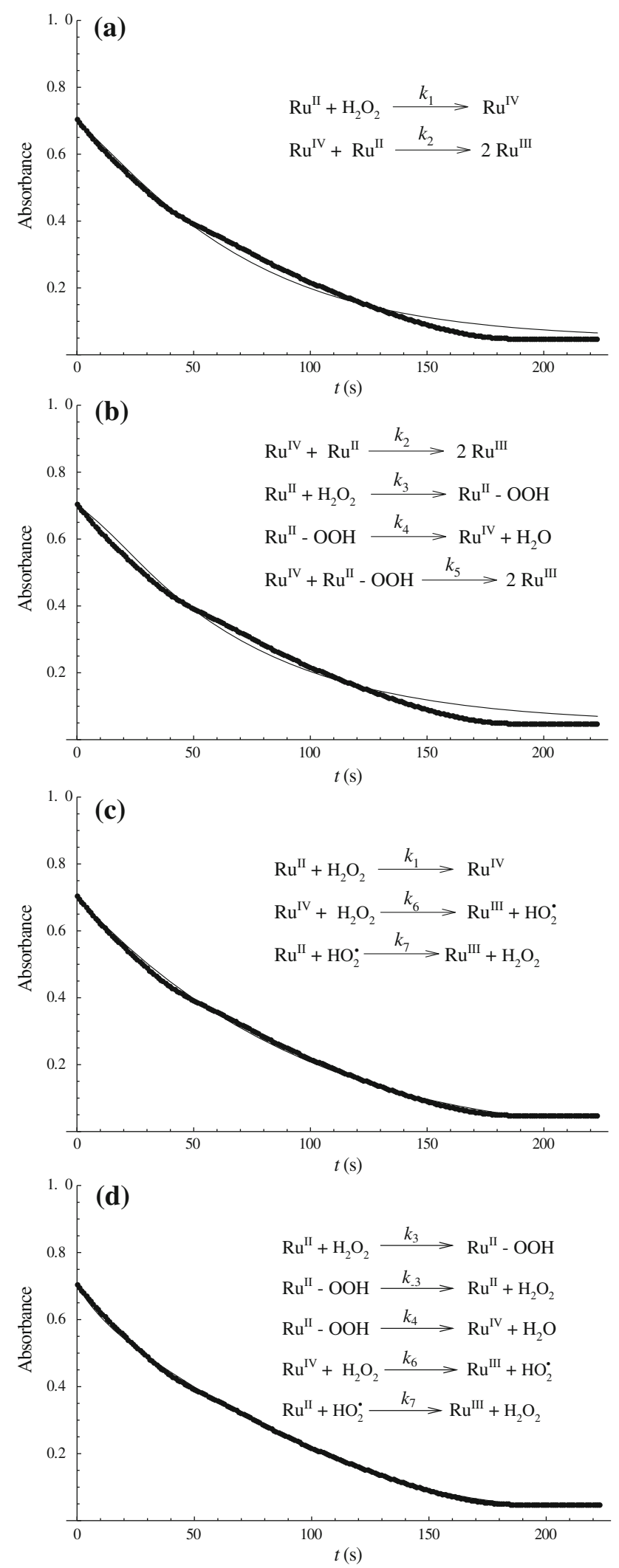

Fig. 9 Examples of fitting of kinetic traces recorded at $472 \mathrm{~nm}$ for the oxidation of $\left[\mathrm{Ru}^{\mathrm{II}}(\text { pic })_{3}\right]^{-}$complex by $\mathrm{H}_{2} \mathrm{O}_{2}$ to some chosen reaction models; $[\mathrm{Ru}(\mathrm{II})]=8 \times 10^{-5} \mathrm{M}, \quad\left[\mathrm{H}_{2} \mathrm{O}_{2}\right]=0.01 \mathrm{M}$, $\left[\mathrm{H}_{3} \mathrm{O}^{+}\right]=0.1 \mathrm{M}, T=298 \mathrm{~K}$. Dots-experimental trace; line-fit transfer. Moreover, the linearity of these dependences suggests a low conversion of the starting complex into the $\mathrm{Ru}-\mathrm{OOH}$ intermediate under the applied conditions. Data obtained from the initial rate method cannot be used for the determination of the numerous parameters specified in Scheme 4. A piece of information on the contribution of the particular reaction stages to the overall oxidation mechanism comes from the detailed analysis of the whole absorbance decrease observed during the reaction. The differential equations describing a specific reaction model were solved for an initial set of parameters using the procedure NDSolve within the program Mathematica $^{\circledR}$ (Wolfram). Figure 9 illustrates the quality of the fit performed using the Simplex algorithm [31] for a few chosen reaction models. Very bad fits shown in Fig. 9a and b rule out an intramolecular electron transfer as the rate determining step and also indicate that $\mathrm{Ru}(\mathrm{II})$ $\mathrm{Ru}(\mathrm{IV})$ comproportionation producing $\mathrm{Ru}(\mathrm{III})$ is of minor importance.

Good fits obtained for the third and fourth models, shown in Fig. 9c and d, emphasize the importance of the oxidation of hydrogen peroxide by ruthenium(IV) and also the formation of peroxoruthenium(II) complex. Regrettably, the method applied for numerous sets of kinetic runs performed under varied concentration conditions does not give a coherent set of kinetic parameters. Nevertheless, the applied numerical method confirms a key role of the $\mathrm{Ru}^{\mathrm{II}}$ $\mathrm{OOH}$ intermediate formation stage, its redox decomposition producing ruthenium(IV), and the reduction of the latter species by hydrogen peroxide.

This is additionally confirmed by the independence of the $k^{\mathrm{II}}$ of the ionic strength, Table 1. Furthermore, this method demonstrates the minor importance of the $\mathrm{Ru}(\mathrm{II})$ $\mathrm{Ru}(\mathrm{IV})$ comproportionation step for ruthenium(II) disappearance in the overall redox process for all the performed kinetic experiments.

Taking into account potential pharmaceutical applications of the $\left[\mathrm{Ru}(\mathrm{pic})_{3}\right]^{0 /-}$ complexes, it seems interesting to summarize the available kinetic data found in vitro for the redox transformations of the ruthenium complexes caused by chosen biomolecules or their mimics. Half-reaction times calculated for the arbitrary chosen initial concentrations of the reactants being in an excess over ruthenium concentration are collected in Table 4.

As seen, redox inertness and transformation only to ruthenium(III) are characteristic for the $\left[\mathrm{Ru}(\mathrm{pic})_{3}\right]^{-}$anion, the only starting reductant without any water ligand in the inner coordination sphere. Moreover, the reduction in the $\left[\mathrm{Ru}(\mathrm{pic})_{3}\right]^{0}$ to the $\left[\mathrm{Ru}(\mathrm{pic})_{3}\right]^{-}$anion is a very fast process. Summing up, it is likely that in biological systems, ruthenium trispicolinato species applicated either as ruthenium(III) or ruthenium(II) should also exist predominately as the $\left[\mathrm{Ru}(\mathrm{pic})_{3}\right]^{-}$anion. 
Table 4 Approximated values of the half-time for ruthenium redox transformation caused by some biological reactants $\left(1 \times 10^{-5} \mathrm{M}\right)$ being in an excess over ruthenium species; $T=298 \mathrm{~K}$

\begin{tabular}{|c|c|c|c|c|}
\hline Complex & Reactant & $\mathrm{pH}$ & $\mathrm{t}_{1 / 2}(\mathrm{~s})$ & Ref. \\
\hline \multicolumn{5}{|l|}{$\mathrm{Ru}(\mathrm{II}) \rightarrow \mathrm{Ru}(\mathrm{III})$} \\
\hline$\left[\mathrm{Ru}(\mathrm{pic})_{3}\right]^{-}$ & $\mathrm{H}_{2} \mathrm{O}_{2}$ & 1.0 & $248,000(69 \mathrm{~h})$ & This work \\
\hline$\left[\mathrm{Ru}(\mathrm{pic})_{3}\right]^{-}$ & $\mathrm{H}_{2} \mathrm{O}_{2}$ & 7.4 & $37,000,000$ (1.2 years) & This work \\
\hline$\left[\mathrm{Ru}(\mathrm{pic})_{3}\right]^{-}$ & $\mathrm{O}_{2}$ & 1.0 & $154,000(43 \mathrm{~h})$ & This work \\
\hline$\left[\mathrm{Ru}(\mathrm{pic})_{3}\right]^{-}$ & $\mathrm{O}_{2}$ & 7.4 & $18,480,000$ (0.6 years) & This work \\
\hline \multicolumn{5}{|l|}{$\mathrm{Ru}(\mathrm{II}) \rightarrow \mathrm{Ru}(\mathrm{IV})+\mathrm{Ru}(\mathrm{VI})$} \\
\hline$\left[\mathrm{Ru}(\mathrm{dmphen})_{2}\left(\mathrm{H}_{2} \mathrm{O}\right)_{2}\right]^{2+}$ & $\mathrm{H}_{2} \mathrm{O}_{2}$ & $3.3-9.1$ & $217,000(60 \mathrm{~h})$ & [21] \\
\hline \multicolumn{5}{|l|}{$\mathrm{Ru}(\mathrm{III}) \rightarrow \mathrm{Ru}(\mathrm{IV})+\mathrm{Ru}(\mathrm{V})$} \\
\hline$\left[\mathrm{Ru}(\text { edta })\left(\mathrm{H}_{2} \mathrm{O}\right)\right]^{-}$ & $\mathrm{H}_{2} \mathrm{O}_{2}$ & 5.1 & $2,600(0.7 \mathrm{~h})$ & {$[24]$} \\
\hline \multicolumn{5}{|l|}{$\mathrm{Ru}(\mathrm{III}) \rightarrow \mathrm{Ru}(\mathrm{II})$} \\
\hline trans $-\left[\mathrm{RuCl}_{4}(\mathrm{dmso})(\mathrm{Im})\right]$ & Ascorbic acid & 5.0 & $2,900(0.8 \mathrm{~h})$ & {$[11]$} \\
\hline$\left[\mathrm{Ru}(\mathrm{dpic})_{2}\right]^{-}$ & Ascorbic acid & 4.0 & $3,500(1 \mathrm{~h})$ & {$[32]$} \\
\hline$\left[\mathrm{Ru}(\mathrm{dpic})_{2}\right]^{-}$ & Ascorbic acid & 8.0 & 50 & {$[32]$} \\
\hline$\left[\mathrm{Ru}(\mathrm{pic})_{3}\right]^{0}$ & Cytochrome cII & 5.4 & 0.016 & [19] \\
\hline$\left[\mathrm{Ru}(\mathrm{pic})_{3}\right]^{0}$ & {$\left[\mathrm{Co}(\mathrm{bpy})_{3}\right]^{2+}$} & 5.4 & 0.11 & [19] \\
\hline$[\mathrm{Ru}(\text { edta }) \mathrm{pz}]^{-}$ & Cysteine & 5.1 & $12,000(3.3 \mathrm{~h})$ & {$[33]$} \\
\hline$[\mathrm{Ru}(\text { edta }) \mathrm{pz}]^{-}$ & Glutathione & 5.1 & $23,000(6.3 \mathrm{~h})$ & [33] \\
\hline
\end{tabular}

Acknowledgments The authors wish to express their gratitude to Prof. Stanisław Koter (N. Copernicus University) for the computational calculations and to Prof. Janusz Szklarzewicz (Jagiellonian University, Cracow Poland) for his kind help in carrying out the cyclic voltammetry measurements.

Open Access This article is distributed under the terms of the Creative Commons Attribution Noncommercial License which permits any noncommercial use, distribution, and reproduction in any medium, provided the original author(s) and source are credited.

\section{References}

1. Chow CK, Ibrahim W, Wei Z, Chan AC (1999) Free Radic Biol Med 27:580-587

2. Nishikawa M (2008) Cancer Lett 266:53-59

3. López-Lázaro M (2007) Cancer Lett 252:1-8

4. Denisov IG, Makris TM, Sligar SG, Schlichting I (2005) Chem Rev 105:2253-2277

5. Kryatov SV, Rybak-Akimova EV, Schindler S (2005) Chem Rev $105: 2175-2226$

6. Afanasiev P, Kudrik EV, Millet JMM, Bouchu D, Sorokin AM (2011) Dalton Trans 40:701-710

7. Levina A, Mitra A, Lay PA (2009) Metallomics 6:458-470

8. Jones CJ, Thornback JR (2007) Medicinal applications of coordination chemistry. RSC Publishing, Cambridge

9. Alpeeva IS, Soukharev VS, Alexandrova L, Shilova NV, Bovin NV, Csöregi E, Ryabov AD, Sakharov IY (2003) J Biol Inorg Chem 8:683-688

10. Karki SS, Thota S, Darj SY, Balzarini J, De Clercq E (2007) Bioorg Med Chem 15:6632-6641

11. Brindell M, Piotrowska D, Shoukry AA, Stochel G, van Eldik R (2007) J Biol Inorg Chem 12:809-818

12. Brindell M, Stawoska D, Supel J, Skoczowski A, Stochel G, van Eldik R (2007) J Biol Inorg Chem 13:909-918
13. Kingry KF, Royer AC, Vincent JB (1998) J Inorg Bioch 72: 79-88

14. Yoshikawa Y, Ueda E, Kawabe K, Miyake H, Takino T, Sakurai H, Kojima Y (2002) J Biol Inorg Chem 7:68-73

15. Rehder D, Pessoa JC, Geraldes CFGC, Castro MMCA, Kabanos T, Kiss T, Meier B, Micera G, Pettersson L, Rangel M, Salifoglou A, Turel I, Wang D (2002) J Biol Inorg Chem 7:384-396

16. Barral MC, Jiménez-Aparicio R, Royer EC, Saucedo MJ, Urbanos FA, Gutiérrez-Puebla E, Ruíz-Valero C (1991) J Chem Soc Dalton Trans:(6)1609-1613

17. Ghatak N, Chakravarty J, Bhattacharya S (1995) Polyhedron 14:3591-3597

18. Impert O, Katafias A, Kita P, Wrzeszcz G, Lente G, Fábián I (2011) Transition Met Chem 36:761-766

19. Ellis RM, Quilligan JD, Williams NH, Yandell JK (1989) Aust J Chem 42:1-7

20. Aebischer N, Laurenczy G, Ludi A, Merbach AE (1993) Inorg Chem 32:2810-2814

21. Robbins MH, Drago RS (1996) J Chem Soc Dalton Trans:(1)105-110

22. Atkins P, Overton T, Rourke J, Weller M, Armstrong F (2010) Shriver \& Atkins inorganic chemistry, 5th edn. Oxford University Press, Oxford

23. Gilbert J, Roecker L, Meyer TJ (1987) Inorg Chem 26: $1126-1132$

24. Chatterjee D, Mitra A, van Eldik R (2007) Dalton Trans: (9) $943-948$

25. Liu F, Concepcion JJ, Jurss JW, Cardolaccia T, Templeton JL, Meyer TJ (2008) Inorg Chem 47:1727-1752

26. Hurst JK, Cape JL, Clark AE, Das S, Qin C (2008) Inorg Chem 47:1753-1764

27. Muckerman JT, Polyansky DE, Wada T, Tanaka K, Fujita E (2008) Inorg Chem 47:1787-1802

28. Romero I, Rodriguez M, Sens C, Mola J, Kollipara MR, Fràncas L, Mas-Marza E, Escriche L, Llobet A (2008) Inorg Chem 47:1824-1834

29. Deng Z, Tseng HW, Zong R, Wang D, Thummel R (2008) Inorg Chem 47:1835-1848 
30. Betley TA, Wu Q, Voorhis TV, Nocera DG (2008) Inorg Chem 47:1849-1861

31. Himmelblau DM (1972) Applied nonlinear programming. McGraw-Hill, New York, p 451
32. Williams NH, Yandell JK (1983) Aust J Chem 36:2377-2386

33. Chatterjee D, Pal U, Ghosh S, van Eldik R (2011) Dalton Trans 40:1302-1306 